\title{
Formation and Implementation of a Common EU Security and Defense Policy (CSDP) (1992-2019)
}

\author{
Kanan K. Dadashov \\ Moscow State Institute of International Relations (MGIMO- \\ University) of the Ministry of Foreign Affairs of the \\ Russian Federation \\ Moscow, Russia
}

\author{
Svetlana A. Arbuzova, Svetlana V. Ivanova, Aleksey \\ V. Azarkhin, Evgenii N. Zinkov \\ Samara State University of Economics \\ Samara, Russia. \\ Samara Law Institute of the Federal Penitentiary Service of \\ Russia \\ Samara, Russia
}

\begin{abstract}
The article argues that the European Union's Common Security and Defense Policy (CSDP), from 1992 to 2019, allows the Union to play a leading role in peacekeeping operations, conflict prevention and strengthening international security. It is an integral part of the EU's integrated crisis management approach, based on civilian and military assets. To give the European Union the opportunity to assume responsibility for crisis management, the European Council (Nice, December 2000) created permanent political and military structures. The Political and Security Committee meets every year at the ambassadorial level as a preparatory body for the $\mathrm{EU}$ Council to monitor the international situation within the framework of the common foreign and security policy.
\end{abstract}

Keywords-European Union; security; EU CSDP; 1992; 2019; Europe; politics; committee on political issues and security; crisis; responsibility

\section{INTRODUCTION}

The end of the Cold War and the collapse of the USSR marked the emergence of a qualitatively new system of international relations. One of the direct results of this transition of international actors to a fundamentally different level of relations was a fundamental change in the nature of the security of their interactions. In modern realities, regionalization processes acquire sufficiently clear signs, in which regional security structures play a more prominent role.

These processes are also characteristic for the European Union, which in the era of post-bipolarity has moved from a predominantly economic integration model to a qualitatively new phase of integration - the political one. The logical development of this political component was the "overflowing" of integration into the military-political sphere.

\section{MethODOLOGY}

The methodological basis of the study is based on the concept of a comprehensive study of the CSDP of the EU. The development of a unified system of methods is based on the use of the system, dialectical and theoretical-methodological approaches.
The systems approach has been used, as the CSDP is considered as a holistic phenomenon in the EU structure, the components of which are interrelated and interdependent.

The dialectical approach has been applied in the context of interpreting the CSDP as a dynamic system of principles and rules of relations between EU member states and with the third parties. This system is in a permanent state of transformation, due to the contradictory nature of a two-level practice: at the level of the security systems of the EU member states, including the international security system in a specific historical situation as a whole.

In order to highlight the factors of European integration in the field of security and defense of the EU, the author used the historical method. This method was also applied to analyze certain facts and events that took place within the framework of the research object.

\section{RESULTS AND DISCUSSION}

The outlines of the Common Security and Defense Policy emerged in the 1990s., in the Petersburg Declaration of the Western European Union [15] (1992) and the Joint Declaration on the Defense of Europe [13] (1998). However the conflict in the former Yugoslavia (1991-1995), the Kosovo crisis (1999), the terrorist attacks in the USA (2001) and the war in Iraq (2003) revealed the unpreparedness of a united Europe to act quickly and effectively, as the circumstances require, to resolve crisis situations.

This is not surprising, since the subject of the Common Foreign and Security Policy was not clearly defined in the Maastricht Treaty. Only the Treaty of Amsterdam (1997) for the first time provided the EU with a military dimension, directly incorporating security and defense issues into the competence of the European Union. But the formation of the European security and defense policy began only in 1999.

The beginning of the 21 st century was marked by the intention of the Europeans to build a European (after the Lisbon Treaty) security and defense policy as an integral part of a common foreign and security policy [2]. Since there was a 
significant difference between the EU member states in the field of military culture, standards, and approaches to ensuring security, great importance in the formation of the CSDP, was paid to the issues of military-technical cooperation, as well as the development of a common strategy and concepts for resolving crises. The first steps in this direction were made in 2002, when the principles of the strategic partnership of the Alliance and the EU were enshrined in the NATO-EU Declaration on the European Security and Defense Policy [9] and in the so-called Berlin Plus agreements [1], which defined the order of access of the European Union to NATO resources and the conditions of their joint or independent activities in resolving crisis and conflict situations. A year later, in 2003, the European Security Strategy (hereinafter - the ESS) [12] and the EU Strategy against Proliferation of Weapons of Mass Destruction [11] were developed and adopted. In 2005 the EU adopted a counter-terrorism strategy [17].

The ESS noted that long-term solutions to resolve conflicts should unite all regional players who place stake on restoring peace. At the same time, sovereign governments should assume responsibility for ensuring respect for the sovereignty, independence and territorial integrity of states, as well as the peaceful resolution of differences, that is, adherence to the fundamental principles of the UN Charter, as well as the principles and commitments of the OSCE.

In 2005 The European Union adopted another document the European Consensus on Development [18]. It is significant that, both in the ESS and in the European Consensus, it was stressed that sustainable development is impossible without a peaceful and secure environment, and lasting peace is impossible without development and the elimination of poverty

The lack of funding for the armed forces of European countries directly affected the process of enhancing their expeditionary capabilities. In accordance with NATO requirements, the armed forces must meet two basic criteria for expedition operations, namely:

1) The ground component of the Armed Forces capable of deploying outside the country must be at least $40 \%$ of the total strength;

2) The ground component of the Armed Forces, constantly deployed outside the national territory as part of expeditionary operations - at least $8 \%$ [8, p. 156].

During 2009-2010 the main efforts of the EU authorities were aimed at overcoming the negative trends in the development of defense cooperation in the framework of the implementation of the CSDP. In the second half of 2009 the European Union managed to achieve some progress in the CSDP. The main achievements were the following:

- Creation of conditions for the start of the EU's work on the training of security forces in Somalia (training up to 2,000 security forces in Uganda with the help of African Union forces and resources);

- Full implementation of operational and combat training program of the European Rapid Reaction Force, including the implementation of the preparation of command and staff exercises MILEX-2010 (June 16-25, 2010), the main purpose of which was to test the readiness of the military authorities of the strategic and operational levels of the EU and the member states to plan and conduct a military operation to resolve a crisis situation;

- Reaching an agreement to improve the interaction and coordination between civilian and military structures on monitoring the situation in the water area (in the Mediterranean Sea and in northern Europe), as well as improvement of interaction between the European Maritime Safety Agency, the European Agency for Management - operational cooperation on external borders of the EU countries and the European Defense Agency;

- Reaching a common understanding on the desirability of simplifying procedures for the use of combat tactical groups of the EU, as well as improving of coordination the actions of the contributing countries at all stages of activating military technical groups to respond to crisis.

According to the Europeans, the steps taken in the formation of CSDP were quite effective. At the same time, as indicated in the report "On the Implementation of the European Security Strategy" [16] (in 2008), the international community expects much more from the European Union. As it is follows from the European Security Strategy, in the field of security and defense, member states should put into practice the idea of the EU's responsibility for global security.

To do this, they should strive to achieve the following key objectives: strengthening and increasing the effectiveness of the contribution of the EU member states to a new and better system of global governance based on the principles of peace, stability and effective multilateralism; ensuring the status of Europe as a reliable global, and not just a regional actor; ensuring the safety of EU citizens.

For 60 years, NATO and the USA as its core have provided European defense. Under these conditions, especially after the end of the Cold War, the Europeans are used to saving on their own defense, shifting this burden onto the shoulders of the United States. However, at the beginning of the XXI century it turned out that even the US lacks the capacity to respond to new security challenges. Two factors stimulated the search for ways to ensure security in Europe by own efforts: the weakening of transatlantic relations (especially against the background of skeptical evaluations of the Alliance by President D. Trump) and the desire of the leaders of European integration, primarily Germany and France, to deepen cooperation further. At the same time, close transatlantic ties have affected the national positions of the EU member states on the CSDP.

The influence of atlantism was particularly noticeable during the preparation and review in June 2016 of the EU Global Strategy on Foreign and Security Policy. None of the innovative ideas (the creation of a European army, the European General Staff, the European Defense Fund) has been specified in the Strategy. The Atlanticists (Great Britain, Lithuania, Latvia, Estonia and Poland) strongly oppose these ideas; their position is supported by a group of countries (Ireland, Austria, Sweden and Finland), which fear that by 
betting on the European army, they may become involved in an armed conflict.

On June 28, 2016, High Representative of the European Union for Foreign Affairs and Security Policy Mogherini presented the European Union's Global Strategy on Foreign and Security Policy "Shared Vision, Common Approach: A Stronger Europe" [6]. The Strategy notes that "in the modern world," soft "power is not enough, it is necessary to increase the effectiveness of the EU in the field of security and defense" [6].

In 2017, Member States decided to use Article 42 and Article 46 of the Lisbon Treaty for the development of the CSDP, which provide an opportunity for certain EU countries to strengthen their cooperation in military issues by creating a permanent cooperation structure. To this end, the countries concerned must fulfill the conditions contained in Protocol No. 10 appended to the Treaty. [3]. Under the patronage of the European Council, the Permanent Structural Cooperation Program (PESCO) in the field of defense was initiated.

The first step was the submission by Member States in September 2017 of a list of general obligations arising from Protocol No. 10 of the Treaty, in particular, investment in defense, capacity development and operational readiness for defense. At the second stage (November 13, 2017) the ministers from twenty-three EU member states (Austria, Belgium, Bulgaria, Czech Republic, Croatia, Cyprus, Estonia, Finland, France, Germany, Greece, Hungary, Italy, Latvia, Lithuania, Luxembourg, the Netherlands, Poland, Romania, Slovakia, Slovenia, Spain and Sweden) signed a statement of intent to join PESCO.

In doing so, they informed the Council of the EU and the High Representative of the Union for Foreign and Security Policy about a list of joint obligations, noting that they are ready and able to fulfill the requirements in the framework of ongoing structural defense cooperation. At the third stage (approximately December 11, 2017), the EU Council should approve the creation of PESCO by a qualified majority.

The military facilities developed within the PESCO framework remain in the hands of the member states, which can also use them in other formats, such as NATO or the UN [14]. This initiative was commended in the US and NATO. NATO Secretary General Stoltenberg congratulated the new EU declaration of joining the PESCO program, noting that strong European defense has the potential to help to increase defense spending, provide new opportunities and improve the distribution of workload within the Alliance.

Within the framework of the study, the classification of factors responsible for the formation and evolution of the CSDP in the 1990s and the beginning of the 21st century is important. Moreover, it is necessary to take into account the division into internal and external, power and non-force, systemic and non-systemic, factors of interaction and interdependence.

The main reasons for forming of the CSDP into a separate direction of the EU activity have been events in Europe and the world in the field of security since the end of the 1990s., and in the beginning of the XXI century [7, p. 178]. In this regard, the key factors for the evolution of the CSDP during this period were: the crisis of the common foreign and security policy of the EU; manifestation of the conflict potential of the postbipolar era in the immediate vicinity of the EU borders - in the Balkans; the terrorist attacks of September 11, 2001 in New York; the formation of the EU's global security vision and the awareness of the European Union of its role as a global player in security; differences of the EU member states in the vision of future CSDP development; EU enlargement to the east and to the Mediterranean region [5].

From 2005 to 2015, defense spending of 27 EU countries decreased by almost $11 \%$ and reached a total of 200 billion euros. The share of defense spending in GDP also reached its lowest level $-1.4 \%$ in 2015. At the same time, China has increased its military budget by $150 \%$ over the past 10 years. In 2015, Russia invested 5.4\% of its GDP in defense [4, p. 140].

The downward trend in defense budgets is intensifying due to their inefficient use. Fragmentation of European markets leads to unnecessary duplication. Reducing defense spending across Europe did not contribute to increased cooperation, on the contrary, led to its limitation. Nowadays there are fewer joint programs in the EU than 20 years ago. The Plan notes that the defense industry sector is of strategic importance not only for EU security. With a total turnover of 100 billion euros per year, it is also the driving force of the European economy.

An important role is also played by the European Defense Fund, which consists of two separate financial structures ("windows"), which complement each other and will be implemented step by step in a long time. The "research window" is intended to finance joint defense research projects at the EU level. The European Commission, as a first step, has already proposed a budget of 90 million euros for the period 2017-2019. [1].

In the future, the research budget will reach 500 million euros per year. To increase investment in defense, it is proposed to take full advantage of the opportunities already provided for by the founding treaties of the EU, in particular, in Article 174 of the Treaty on the Functioning of the European Union [18].

The Common Security and Defense Policy was formally based on the EU Summit in Cologne in June 1999 as part of the implementation of the EU Common Foreign and Security Policy. The entry into force of the EU Treaty of Lisbon (from December 1, 2009) made it possible to unblock the process of strengthening European institutions and to create a full-fledged regulatory and legal framework for the CSDP.

Processes related to the integration of the defense-industrial complexes of the EU countries, the creation of a single European market for defense products, the strengthening of the European Union's military capabilities to respond quickly to crisis situations have been further developed. The EU's contribution to international peacekeeping activities has increased due to the opening of new operations in the framework of the CSDP (Afghanistan, Africa / Somalia, Kosovo).

At the same time, the persistence of significant differences between EU countries on the development paths and goals of 
CSDP, insufficient political will from the leaders of most EU countries, considerable resistance from the US, who see CSDP as a certain threat to transatlantic unity, and a number of other factors continue to negatively influence the process of formation of a European security system.

\section{CONCLUSION}

The article presents a theoretical summary of the study of the international political experience of the European Union in guaranteeing its security in the context of the formation and development of the CSDP and the following conclusions were made:

1. The European security and defense policy is a new phenomenon of international political life, the development dynamics of which is very high. The defining feature of this policy is the contradiction between its ultimate political and strategic goal and its practical implementation, due to the complex nature of the EU as a sui generis organization.

2. The EU became the first in world practice association, which at the international legal level reinforced the desire to create a joint security policy and defense policy of the member states, which in fact means the violation of the exclusive right of the member states to implement their security policy and defense policy independently. It should be immediately noted that this attempt was not fully implemented, but is only at the initial stage.

3. The European security policy and defense policy can be viewed as EU foreign policy activities aimed at the realization of the joint strategic goals of the member states in the field of cooperative security. It can be transformed into a collective security system.

4. The categorical apparatus for the study of European security and defense is determined by the pluralism of approaches. In the western political science literature, there is practically no generally accepted definition of the concept "security"; it is new in the political vocabulary - its active use dates back to the beginning of the 1980s. During the development of CSDP (1992-2019), the concepts of "security" and "defense" and the categories associated with them have undergone significant transformation. Given such a transformation of the conceptual and categorical apparatus (content expansion), the logic of the formation and development of CSDP becomes more understandable.

5. On the basis of identifying the main qualitative characteristics, the periodization of the formation of the security of European cooperation from the post-war period to the present day has been carried out (six stages). It reflects the evolution from informal political consultations to the institutional cooperation of the CSDP. In the context of new security challenges, attempts are being made to undertake strategic and institutional reform. The EU demands a qualitatively new type of military-political leadership.

6. The EU, as a regional security organization in accordance with the UN Charter, faces the urgent task of defining its functional role among other international organizations (NATO, OSCE, UN). Non-traditional asymmetrical threats to international security require coordination not only at the level of national states within international organizations, but also coordination of the activities of these organizations. Consequently, the importance of the principle of multilateralism is increasing, which provides for strengthening the juridical base and the role of international institutions in solving international security problems. The relations of all the organizations studied determine their interdependence.

\section{REFERENCES}

[1] EU budget for 2019, 2019. Available online https://eeas.europa.eu/en/eu-information-russian/45175/en

[2] S. Yu. Kashkin M, The European Union: the founding acts in the wording of the Lisbon Treaty with comments. 2008. 224. (In Russ)

[3] Consolidated versions of the Treaty on European Union and the Treaty on the Functioning of the European Union, 2010. C 83/01. Available online: http://zakon3.rada.gov.ua/laws/show/994_b06/

[4] Kochev I. A, The General Security and Defense Policy of the European Union in Modern Political Theory, Tomsk State University Bulletin. Philosophy. Sociology. Political science, 2011. 3(15). 138-144.

[5] Kuznetsova I. S, The General Security and Defense Policy of the European Union: Conceptual and Practical Aspects Dissertation, 2011. (In Russ.) Available online: http://rep.pac.by/jspui/handle/123456789/258

[6] On the way to strengthening the security and defense of the EU, 2018 Available online: https://eeas.europa.eu/headquarters/headquartershomepage_en.

[7] Novikova O. O, European Union in the system of international security: new tools for crisis settlement, Polis. Political studies. №4. 2008. 174184. (In Russ.)

[8] Prokhorenko I. L, Organizational Theory in the Analysis of Globa Governance, Bulletin of Moscow University. Series 25. International Relations and World Politics. 2014. № 3. 150-173. (In Russ)

[9] EU-NATO Declaration on ESDP, 2002. Available online: https://www.nato.int/cps/en/natolive/official_texts_19544.htm

[10] EU-NATO: The Framework for Permanent Relations and Berlin Plus, 2002. Council of the European Union, Available online: http://www.consilium.europa.eu/uedocs/cmsUpload/03-11$11 \% 20$ Berlin\%20 Plus\%20press\%20note\%20BL.pdf

[11] EU strategy against proliferation of Weapons of Mass Destruction, 2003. Available online: http://register.consilium.europa.eu/pdf/ en/03/st15/st15708.en03.pdf .

[12] European Global Strategy - A Secure Europe in a Better World, Available online: https://europa.eu/globalstrategy/en/europeansecuritystrategy-secure-europe-better-world.

[13] Joint Declaration issued at British-French Summit in Saint-Malo, December 3-4, 1998. From St-Malo to Nice. European Defense: Core Documents. Chaillot Papers, №47. Paris. 2001. 8-9.

[14] Permanent Structured Cooperation - PESCO Deepening Defense Cooperation among EU Member States, 2017. Available online: https:// eeas.europa.eu/sites/eeas/files/pesco_factsheet_19 10 2017_1.pdf

[15] Petersburg Declaration, 19 June 1992 Western European Union Council of Ministers. Bonn. Available online: http://www.bits.de/NRANEU/docs/petersberg92.pdf

[16] Report on the Implementation of the European Security Strategy Providing Security in a Changing World, 2008. Available online: https://europa.eu/globalstrategy/en/report-implementationeuropeansecurity-strategy-providing-security-changing-world.

[17] The European Union Counter-Terrorism Strategy, 30 Nov. 2005. Doc. 14469.4.05, Council of the European Union. Brussels. Available online: https://register.consilium.europa.eu/doc/srv?1=EN\&f=ST\%2014469\%20 $2005 \% 20$ REV\%204.

[18] The European Consensus on Development, https://ec.europa.eu/europeaid/sites/devco/files/publication-theeuropeanconsensus-on-development-200606_en.pdf. 